\title{
Assessment of the operation of the Piechcin Diving Centre (Piechain Base) in the OPINION OF RESPONDENTS
}

\section{Jolanta B. Cichowska}

The Jan and Jędrzej Śniadeccy Uniwersity of Science and Technology in Bydgoszcz, Poland

\section{ABSTRACT}

This paper presents an in-depth (in comparison to the pilot studies conducted in 2017) analysis of the offering of the Piechcin recreational dive area. The intention was to check whether the current service offering translates into customer satisfaction, and the activities undertaken on site correlate with the reasons why divers choose this place. In addition, it was established whether the proposal to introduce additional facilities for visitors to the site would translate into their return to the location. The main obstacles to the lack of frequent implementation of dives in Piechcin and infrastructural problems of the reservoir were identified. Particular attention has been paid to the competences and creativity of the organiser of this form of recreation, since personal potential is often a determinant of the success of the business (including in particular ensuring the safety of visitors).

Keywords: diving, competitiveness, security.

\section{ARTICLE INFO}

PolHypRes 2019 Vol. 69 Issue 4 pp. $97-110$

ISSN: $1734-7009$ elSSN: $2084-0535$

DOI: $10.2478 /$ phr-2019-0024

Pages: 14, figures: 5 , tables: 3

page www of the periodical: www.phr.net.pl

\section{Review article}

Submission date: 20.08.2019 r.

Publisher

Polish Hyperbaric Medicine and Technology Society 


\section{INTRODUCTION}

Human underwater activity in the modern world manifests itself in three forms of diving. These are: diving for commercial purposes, diving for military and special tasks, and recreational diving. They differ in purpose, degree of their formalisation, and medical and technical security [1]. Tourist (recreational) diving is an increasingly popular form of spending free time in the country by people of different ages. According to Jóźwiak et al. [2] this activity requires training, usually in the form of a short (several-day) course. The authors note that by its essence, recreational diving, perceived as occasional and seasonal, may pose a threat to people practising this form of recreation.

This is due to the lack of continuous training sustaining habits or reflexes or insufficient cyclicality of repeating emergency procedures (as e.g. military divers are required to follow). Therefore, people undertaking this activity should know the specific requirements and qualifications for those who want to practice scuba diving, how to obtain these qualifications and observe safety rules. Similarly, the organisers of recreational diving sites must create safe conditions for divers in accordance with the applicable law. They are regulated by selected articles of national laws $[3,4,5,6]$, PN-EN norms (Polish Standard for the Introduction of the European Standard) [7] and internal regulations of the Polish Underwater Training Centre of the Polish Tourist and Country-Lovers' Association Underwater Training Committee (KDP OCSP PTTK) [8]. Bodies of water prepared for the training of divers, conducting courses for them or rendered available for use by other clubs and diving centres are most often flooded quarries or pits. According to Zawadzki [9], they are forms of terrain with a unique character owing to considerable depths, vertical walls (as reference points during advanced courses), water transparency, sunken elements of equipment and well-developed surface infrastructure (e.g. exercise platforms, car parks, catering facilities).

With good organisation, water facilities fit perfectly into the surrounding landscape and, as is the case with the Piechcin site, can be an element of sustainable rural development. They become new ecosystems with an increased diversity of landscape (including flora and fauna), which have transformed the usable function of a place from industrial to recreational. The measure of this attractiveness is the expectations of the potential users [10], and the very process of development and comprehensive use of the basins together with their surroundings is conditioned by the demand for a specific social function and the value of the surroundings, which often dictates this and no other form of use. [11]. In the case of the Piechcin reservoir, its function has for many years been focused on a specific recipient (diver) and his or her needs. The aim of the study is to analyse the reservoir in terms of safe management for consumers and to draw attention to which conditions (infrastructural, interpersonal) make customers want to come here again.

At the same time, it was important to determine what kind of activities divers undertake (e.g. training or typical tourist dives) and what they expect from the organiser of the site in terms of improving conditions related to their stay. This paper attempts to assess the role of the activities conducted on a regional scale and in terms of the financial resources invested from the Regional Programme - National Cohesion Strategy. The subject matter seems to be justified because, as Berbeka emphasised eleven years earlier [12], diving is still a modern, extremely dynamically developing sport, the scope of which is systematically expanding, with new trends in consumer behaviour resulting from modified value systems, preferences for lifestyles or a different perception of the quality of life.

In the context of the above indications, the work may provide cognitive material as to the direction of the organisation of such services in the future, by revealing the direct expectations of divers in terms of eliminating the probability of underwater emergencies and improving infrastructure conditions outside the body of water.

\section{MATERIAL AND METHODS}

The survey was conducted in 2018 on a group of 225 divers. The assumption of the prepared interview questionnaire was to determine:

- the reasons why consumers come to Piechcin and with what frequency and in which seasons of the year they use the body of water most often,

- the main activities undertaken by the visitors (including those additional to diving),

- the safety of the basin in terms of underwater and surface infrastructure and the reliability of rented diving equipment,

- the level of quality of the infrastructure elements contributing to the stay in the base,

- the type of amenities that would increase the number of visits to the Piechcin basin.

The survey consisted of 27 questions, 2 of which had an open formula. Unlike the one prepared a year earlier (for a pilot study carried out in the Diving Centre on a group of 56 people), this one introduced additional questions relating to the safety of rental equipment and the offering of additional services related to diving. It was examined (using Pearson's $r$ correlation coefficient) to what extent variables (including: amenities offered in the Piechcin site or obstacles to active recreation there) affect the overall frequency of consumers' stays at different times of the year.

Additionally, whether the activities undertaken after the arrival at the site translate into the reasons behind the divers' choice of this place. This information may prove useful in the marketing of the site in the future. In addition to personal data (gender, age, place of residence, education), the respondents also provided information about their diving degrees and participation in trainings organised by the Diving Centre. The contents of the survey were consulted with the owner of the facility under study, and the visitors filled them in personally from August to October.

\section{RESULTS AND DISCUSSION}

The Piechcin basin is a lake, with an area of about 4.5 hectares, which is a remnant of a quarry liquidated in the 1960s (Fig. 1). After its mining exploitation, the pipes, steel plates, cars, a sailing boat or a yacht sunk there made it attractive for underwater enthusiasts (Fig. 2). It is used exclusively for scuba diving and is not intended for other water sports, fishing or swimming [13]. 


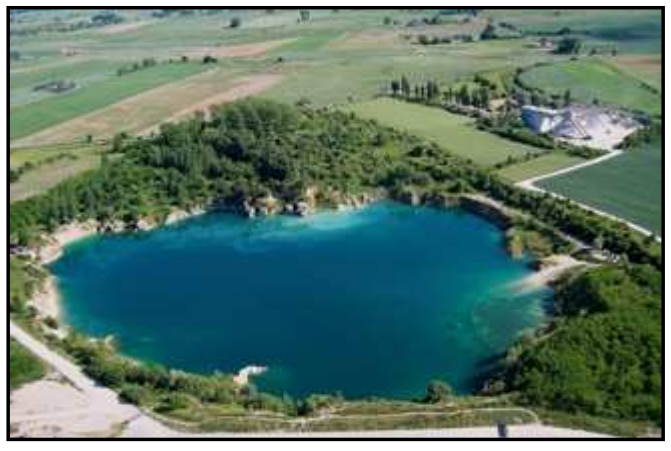

Fig. 1 Bird's eye view of the basin.

Source: photograph made available by the owner of the Piechcin Diving Centre (CNP).

The research shows that $76.4 \%$ of the total number of visitors to the area are men. Consumers are mainly city dwellers (83.5\%) with higher (62.3\%) and secondary $(27 \%)$ education, having mainly primary (28.1\%), secondary (26.2\%) and higher (20.7\%) diving qualifications. The instructor's qualification was held by $12.4 \%$ of the respondents, while the rest $(12.6 \%)$ stated that they were either just trainees or listed the specific preparations they had for this activity. The respondents reported that they obtained diving skills and qualifications (confirmed by qualification cards) from two federations: The World Confederation of Underwater Sports (Confédération Mondiale des Activités Subaquatiques CMAS) and the international organisation - Professional Association of Diving Instructors (PADI).

This first organisation defines the levels of qualification obtained by means of stars. One of the persons surveyed had the first KDP (KDP - Commission for Underwater Activities)/CMAS (P1) diving qualification, allowing them to plan their own dives and perform them to a depth of $20 \mathrm{~m}$ with at least one adult diver with the same or higher KDP/CMAS or other diving organisation qualifications. Another person had already obtained the degree of a more advanced diver KDP/CMAS* (P2), allowing him/her to dive at depths of up to $40 \mathrm{~m}$. In addition, it was noted that two persons who had completed (in the CAMS Recreation Division) the PA1 course Archaeologist Diver, giving the opportunity to dive in a more informed way with regards to the importance of historic objects they may see under water [14], as well as a person with the privileges of Tourist Diver - Supervised KDP/CMAS (PTN), having the right to dive to a depth of $12 \mathrm{~m}$ in the company of an instructor or with a diver with the rank of KDP/CMAS ${ }^{\text {tok }}$ (P3) or the equivalent of other organisations [15]. Within PADI, two respondents had an advanced (recreational) AOWD (Advanced Open Water Diver) qualification, allowing them to dive to a depth of $30 \mathrm{~m}$ with a diver of the same grade.

The qualifications obtained in the AOWD courses allowed four people to take courses to deepen their knowledge and develop their skills in deep diving and underwater rescue, namely the PADI Deep Diver and the PADI Rescue Diver. Having completed the latter training, three people were able to take part in a professional PADI Divemasters diving course (Diving Guide), which gives the opportunity to work in Diving Centres around the world as a dive organiser or guide [16].

Only one person indicated that they were

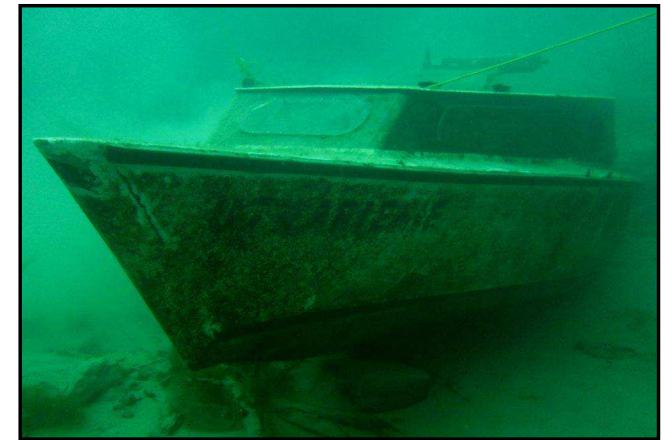

Fig. 2 An element of underwater infrastructure. Source: photograph made available by the owner of the facility (by Jolanta Dereszewska).

prepared to be a technical diving instructor (within the PADI Tec40 CCR Instructor course). In the survey, two respondents also noted that they were there to perform breath-hold dives. It was noted that the level of diving qualifications obtained (training and courses) correlated with the divers' education, as the Pearson $r$ coefficient showed a high correlation of 0.821 in this respect. The higher the general education of the surveyed persons, the more often they possessed high diving qualifications. The respondents have been coming to Piechcin since 1998, i.e. even before the Centre was established (Table 1).

The largest number of people, as many as 77 , visited the basin for the first time in the 2018 research year in the months from July to September (i.e. $39.4 \%$ of the total number of respondents) (Table 1). Since 2011, there has been a steady increase in the number of new customers spending their time in Piechcin. The analysis showed that the respondents represented mainly four age groups: 4044 years (19.8\%), $45-49$ years (16.5\%), and 35-39 years $(15.9 \%)$ and $30-34$ years (14.3\%) (an increase in the percentage of people in the 45-49 age structure, which at that time was not the leading one, was noted compared to 2017). The group of 50 years of age and more included 25 people $(13.7 \%)$, while persons under 19 years of age and $20-29$ years of age accounted for $7.7 \%$ and $12.1 \%$ of the population respectively. The visitors were mainly divers from the following provinces: Kujawsko-Pomorskie (40.8\%), Mazowieckie (22.3\%), Wielkopolskie (16.4\%), Pomorskie (15.4\%). Additionally, people from the following regions were observed: Dolnośląskie (3), Łódzkie (5), Opolskie (1) and Śląskie (1). The average distance from the place of residence of the surveyed persons to the centre was $142.5 \mathrm{~km}$ and increased by 7.5 $\mathrm{km}$ compared to the previous year. 
Years in which the surveyed divers visited the Piechcin reservoir for the first time (with an estimated number of visits until 2018 in total).

\begin{tabular}{|c|c|c|c|}
\hline \multicolumn{4}{|c|}{ Visitors to the Piechcin Reservoir in the years 1998-2010 and the Piechcin Diving Centre (CNP) in the years 2011-2018 } \\
\hline Year & Number of people $*$ & $\begin{array}{l}\text { Number of visits } \\
\text { from given year until } 2018\end{array}$ & $\begin{array}{l}\text { Average number of } \\
\text { visits per person }\end{array}$ \\
\hline 1998 & 1 & 30 & 30 \\
\hline 1999 & 1 & no responses & - \\
\hline 2000 & 4 & 63 & 15,7 \\
\hline 2003 & 3 & 40 & 13,3 \\
\hline 2004 & 1 & 14 & 14 \\
\hline 2005 & 2 & 12 & 6 \\
\hline 2008 & 2 & 300 & 150 \\
\hline 2009 & 5 & 430 & 86 \\
\hline 2010 & 12 & 316 & 26,3 \\
\hline $2011^{* *}$ & 8 & 139 & 17,3 \\
\hline 2012 & 3 & 113 & 37,6 \\
\hline 2013 & 14 & 434 & 31 \\
\hline 2014 & 12 & 110 & 9,1 \\
\hline 2015 & 19 & 146 & 7,6 \\
\hline 2016 & 11 & 186 & 16,9 \\
\hline 2017 & 20 & 145 & 7,2 \\
\hline 2018 & 77 & 128 & 1,6 \\
\hline Total & 195 & 2606 & 13,3 \\
\hline $\begin{array}{l}\text { Total } \\
2011-2018 \\
\end{array}$ & 164 & 1401 & 8,5 \\
\hline Total & 31 & 1205 & 38,8 \\
\hline
\end{tabular}

1998-2010

*30 people did not provide answers as to from which year they have been visiting the Centre and did not specify the approximate frequency of their visits,

** the year of commencement of the Centre's operation.

Source: Own study based on surveys conducted.

The availability of the site during the year was rated high (62.8\% very good and $27.5 \%$ good), as was the offer of equipment rented there $(40.3 \%$ very good and $15 \%$ good) (comparable to 2017). A large group of people used their own equipment and therefore did not express an opinion about it (42.6\%). In individual cases, the ratings given were bad (1) or very bad (1). These were two out of 6 people who encountered malfunctions, namely: a broken diving mask strap (1); a broken flipper strap (3); a lack of an 0-ring on the first stage of the regulator (1); a leaking hoses (1); an empty or only partially filled cylinder (1); a problem with the bleed valves (1) and an unpleasant smell of the air in the cylinder ( 2 people).

The recorded defects may affect the diver's safety, however, according to the regulations of the site, each person is obliged to check the completeness and efficiency of the equipment used not only by themselves but also by their partner before entering the water. Such procedures quickly eliminate any risk to the health and safety of diving participants.

The shortcomings noted did not translate into a safety assessment of the CNP, as $42.4 \%$ of the respondents believe that this is one of the most important aspects that they value in the organiser, after a well organised underwater infrastructure, which received the highest marks $(56.4 \%)$, the availability of the facility throughout the year $(52.8 \%)$, its onshore infrastructure $(49.3 \%)$ and the pleasant atmosphere existing there upon their arrival (45.7\%).

Also appreciated were the social facilities (39.1\%) and, to a lesser extent, the creativity and qualifications of the organiser $(12.4 \%$ vs. $7.5 \%)$ or the possibility of training at various levels (qualifications) (5.7\%). In the open question the importance of the natural and human aspect was emphasised (positive attitude towards others - both people staying and working at the site).

This assessment of the image of the whole facility translates into who the divers come to Piechcin with, as the correlation in this respect showed a significant relationship of 0.487 . The responders most frequently indicated they came in the company of friends $(57.7 \%$; as in 2017, where indications amounted to $60.7 \%$ ), members of Diving Centres (24\%), families (14.6\%), Diving Clubs $(12.8 \%)$. A lower percentage of respondents reported visits with their spouse $(10.2 \%)$ or individually $(7.5 \%)$, with children (5.3\%) (a group not previously reported) or with a tourist group (4.8\%).

Reasons for visiting the described place are mainly dictated by typical touristic considerations (144 persons, i.e. 64\%) and wishing to spend time with friends (110 persons, i.e. $48.8 \%$ ) (Fig. 3). In 2017 these decisions were of a different nature and were mainly based on educational reasons, and they were only followed by social and typically touristic. Among the "others", the ones related to the general values of the basin (its location and water quality) and the possibility for instructors to conduct courses and trainings there were given.

In turn, the three main activities that the respondents in Piechcin are engaged in are typically tourist diving (75.5\%), practice diving (44\%) and training diving (24\%) (these aspects were given the same high 
marks in 2017 - respectively: $83.6 \%$ vs $60 \%$ vs $36.3 \%$ ). Less frequent are night dives (11.1\%), dives accompanied by underwater photography and filming (11.1\%), ice dives or introduction dives $(10.6 \%$ vs $5.3 \%)$. In isolated cases, the following were indicated: retro-style dives (retro divers), breath hold dives, as well as activities limited to observing underwater life by floating on the water surface with a submerged face (when equipped with a mask, snorkel and flippers) (3.5\% in total). With regard to training dives, it should be noted that most of the respondents (92.4\%) perform them with their instructors. A small number of people use the Centre's assistance in this regard, and if it is mainly PADI-OWD (Open Water Diver, Autonomous Diver) basic training and seeking support in preparing for retro dives. A total of 71 such training courses have been attended since 2011 (on average 4 per 1 person). The Piechcin Diving Centre is not an organiser of diving, but only provides the opportunity to use the water body, its surroundings and infrastructure.
Each dive takes place at the site on the sole responsibility of the diving person, who has an absolute obligation to make a personal entry on the diving register immediately after entering the area of the basin. In addition, divers must show that they have compulsory insurance and a valid medical examination (if they do not have one, they are required to fill in an appropriate statement on their health). During training and practice dives, the organiser of the dive is the instructor, and in the case of recreational dives, the person with the highest diving qualifications assigned by the diving pair or group. In the case of dives of organised diving groups, the organiser is the instructor who organises the dive. To ensure safety, qualification cards confirming the divers' qualifications and skills are kept in deposit for the duration of divers' stay.

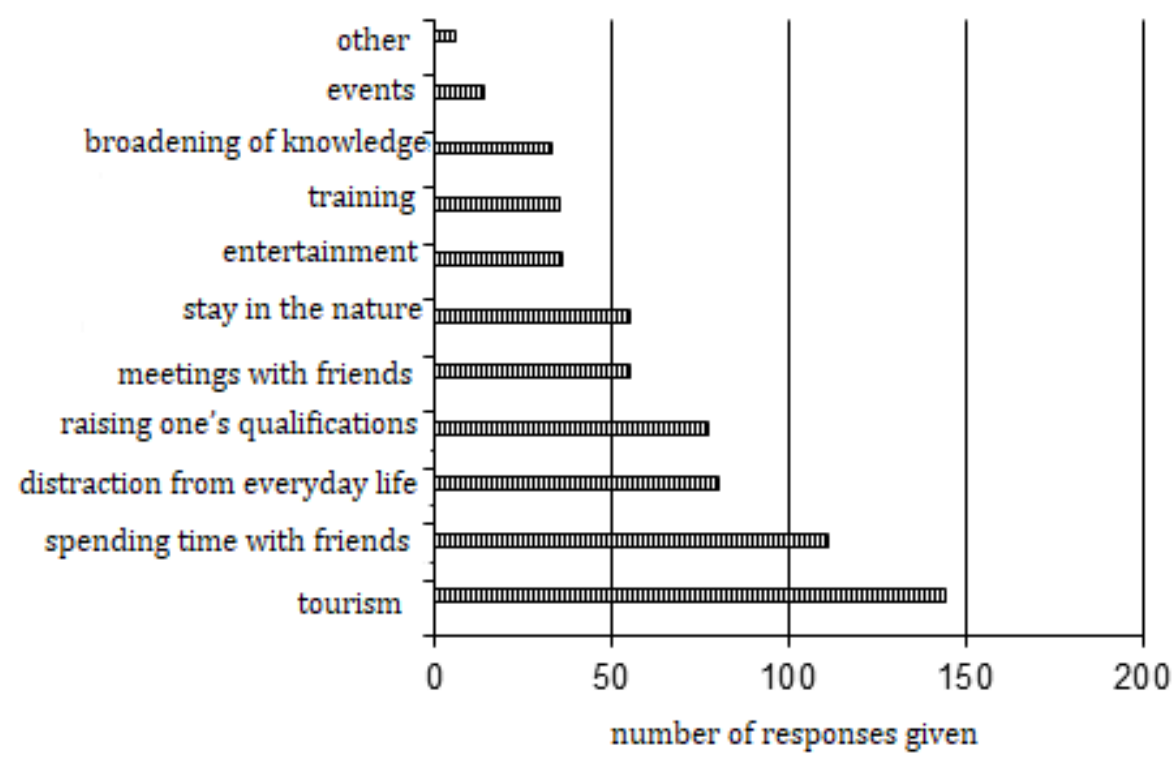

Fig. 3 Reasons for the respondents to visit the Piechcin Diving Centre. Source: Own study based on surveys conducted.

It was analysed whether the type of activities undertaken by the respondents is related to the seasons in which they come to Piechcin. Definitely in the summer and autumn, the most active visits related to recreational, training and night diving are observed. The strength of the correlation is high here (coefficients are at the level of 0.847 and 0.877 respectively). In the spring season, on the other hand, a clear, but not high (0.422) correlation was noted with the divers' participation in training, familiarisation dives and diving related to taking photos and making videos.

In the winter season, the correlation coefficient showed a significant (0.757) correlation with typically touristic, training and under ice dives. Statistics show that the diving centre is visited (similarly to that which was noted in in pilot studies) [17] usually once or twice a year in all seasons (Table 2). In 2017, a slight increase of winter visitors occurred, while in 2018, the visits of divers definitely fell in the summer season (VI-VIII). 
Number of visits to the Piechcin Diving Centre in particular months of the year.

\begin{tabular}{llllll}
\hline No. & Visits to the Diving Centre & $\begin{array}{l}\text { Winter } \\
\text { (XII-II) }\end{array}$ & $\begin{array}{l}\text { Spring } \\
\text { (III-V) }\end{array}$ & $\begin{array}{l}\text { Summer } \\
\text { (VI-VIII) }\end{array}$ & $\begin{array}{l}\text { Autumn } \\
\text { (IX-XII) }\end{array}$ \\
\hline 1. & once a week & 8 & 8 & 13 & 6 \\
\hline 2. & twice a week & 4 & 5 & 7 & 5 \\
\hline 3. & several times a week & 0 & 1 & 4 & 1 \\
\hline 4. & once a month & 12 & 20 & 25 & 19 \\
\hline 5. & twice a month & 1 & 14 & 19 & 14 \\
\hline 6. & several times a month & 2 & 9 & 16 & 6 \\
\hline 7. & once or twice per season & $\mathbf{2 9}$ & $\mathbf{3 6}$ & $\mathbf{4 2}$ & $\mathbf{3 9}$ \\
\hline 8. & once a year & 19 & 11 & 38 & 35 \\
\hline Total* & $\mathbf{7 5}$ & $\mathbf{1 0 4}$ & $\mathbf{1 6 4}$ & $\mathbf{1 2 5}$ \\
\hline
\end{tabular}

* the responses do not add up due to the possibility of providing different answers.

The respondents obtained information about the place under analysis from their friends or acquaintances $(57.3 \%)$ and family (4.4\%). Word-of-mouth marketing played a more significant role in reaching potential new customers than the Internet (24\%). Moreover, $12.9 \%$ of people learned about the existence of the centre directly from their instructors, competitive diving schools, diving centres and clubs, training centres or at diving fairs. A person who became interested in the CNP during the trip through the commune was also recorded.

Promotional materials prepared by the owner in the form of business cards, folders or leaflets were not important for people coming here for the first time (only 5 people in total indicated them). Nevertheless, the divers notice the shortcomings in this respect and direct their expectations towards the facility manager to provide laminated maps of the underwater infrastructure (51.1\%) (to be attached e.g. to a diving noticeboard). Folders $(16 \%)$, business cards $(9.7 \%)$, leaflets $(7.5 \%)$, as well as better promotion on social media, an Internet newsletter for those interested, a mobile website, high-resolution digital maps of the reservoir made available on the Internet, souvenir magnets, noticeboards and billboards ( $8.4 \%$ in total) were also requested. Shortcomings in this respect did not have a significant impact on the overall evaluation of the offer (0.428), the main elements of which were most often attributed high marks (very good and good) (Table 3).

Assessment of the main elements of a stay at a diving centre.

\begin{tabular}{|c|c|c|c|c|c|c|c|}
\hline No. & Elements of assessment & Very good & Good & Average & Bad & Very bad & No opinion \\
\hline \multicolumn{8}{|c|}{ Total in \% } \\
\hline 1. & Social rooms & 52.3 & 40.2 & 2.4 & 0.9 & - & 4.2 \\
\hline 2. & Lecture rooms & 33 & 27.9 & 1.1 & - & - & 38 \\
\hline 3. & Underwater attractions & 48.6 & 42.7 & 5.3 & 0.5 & - & 2.9 \\
\hline 4. & Assistance in booking rooms & 25.8 & 17.9 & 1.5 & - & - & 54.8 \\
\hline 5. & Possibility to rent equipment & 46.8 & 20.5 & 1.4 & - & - & 31.3 \\
\hline 6. & Time of filling diving cylinders with air & 55.8 & 16.9 & 1.4 & - & - & 25.9 \\
\hline 7. & Quality of air in diving cylinders & 49 & 20.8 & 3.3 & - & 0.4 & 26.5 \\
\hline 8. & Possibility of storage equipment & 46 & 22.5 & - & - & - & 31.5 \\
\hline 9. & Instructional services & 26.9 & 11.5 & - & - & - & 61.6 \\
\hline 10. & Parking space & 42.3 & 41.8 & $\mathbf{1 4 . 5}$ & - & - & 1.4 \\
\hline 11. & Courses and trainings & 16.4 & 8.2 & 0.5 & - & 0.5 & 74.4 \\
\hline 12. & Organisation of stays in terms of logistics & 28.5 & 27.5 & 2.0 & - & - & 42 \\
\hline 13. & Tidiness on and around the base & 71.1 & 26.4 & 24 & - & - & - \\
\hline 14. & Safety of the body of water & 58.6 & 34.8 & 1.4 & 0.9 & - & 4.3 \\
\hline 15. & System of promotion & 19.7 & 26.6 & 6.4 & 0.9 & - & 46.4 \\
\hline 16. & Price for the service & 25.6 & 50.3 & 12.8 & 1.9 & 0.4 & 9 \\
\hline 17. & General atmosphere & 72 & 26.2 & 1.0 & 0.4 & - & 0.4 \\
\hline 18. & Sanitary facilities & 47.6 & 37 & 10.1 & 1.4 & - & 3.9 \\
\hline 19. & Diving events & 25.2 & 17.3 & 1.0 & 0.5 & - & 56 \\
\hline 20. & Other (specify of what kind) & 40 & - & - & 10 & - & 50 \\
\hline
\end{tabular}

Source: own study on the bases of surveys conducted. 
Respondents attach particular importance to the positive atmosphere on the site $(72 \%)$, maintaining tidiness in its surroundings $(71.1 \%)$ and ensuring the safety of the basin (58.6\%). The importance of these factors was already emphasised in 2017, with the second highest rank, after the favourable atmosphere $(74.6 \%)$, being given to well organised social facilities (71.1\%), and then the safety of the basin (64\%). All the most important elements of a stay at the Diving Centre were evaluated at a very good and good level. On occasion they were given bad or very bad marks or were not assessed at all.

The latter eventuality was mainly due to insufficient knowledge regarding them. The previously indicated lack of participation in trainings organised at the centre made it impossible to assess the possibilities of improving qualifications (74.4\%), and thus the quality of lecture halls (38\%) and instructor service (61.6\%). Persons using their own diving equipment had no opinion on the methods of its storage (31.5\%), rental (31.3\%) and maintenance ( $25.9 \%$ vs $26.5 \%)$.

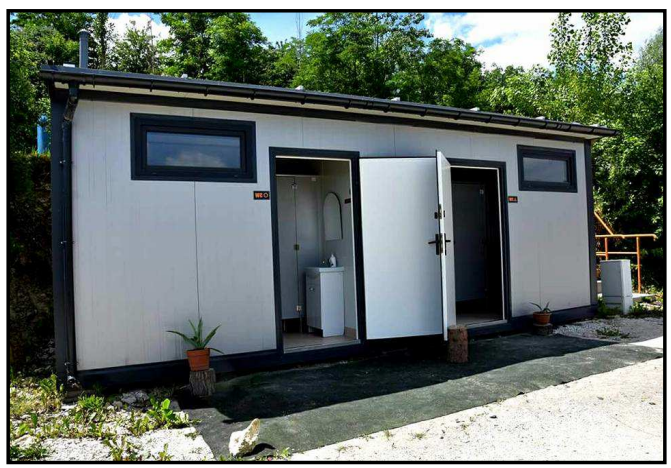

Fig. 4 Container with sanitary facilities. Source: photograph provided by the owner of CNP (by Jolanta Dereszewska).

However, the launch of the catering business is limited by economic and legal procedures. However, for the sake of comfort, the organiser provides divers, as well as the person accompanying them, with a heated room equipped with seating and kitchen equipment. Due to the utilisation of the area by families with children, the respondents expect a playground for children equipped with a sandpit and the introduction of protection against too much sun during the holiday season. In addition, they expect a pier for people accompanying the divers, a sauna, a camping site, as well as an increase in accommodation.

Satisfying these needs is important for the visitors to Piechcin, as apart from diving, they are willing to engage in additional activities such as: BBQs (48.8\%), feasting by a bonfire (40\%), ordinary swimming $(22.6 \%)$, walking (15.1\%), running (6.6\%), cycling (4\%) or paddling in a boat or kayak in nearby waters $(3.1 \%)$.

At the same time, attention was drawn to the need to expand the diving equipment storage rooms and extend the parking area. There were requests to prepare additional access points to the water (including high benches), preparation stands, handrails and more availability of water for washing equipment. In terms of underwater infrastructure, it was proposed to make the basin more attractive with new exhibits, namely: aircraft, pipes, wrecks.

According to the owner, some of the proposals are not economically justified, because, for example, the amount spent on the purchase and sinking of an airplane
The lack of knowledge of the promotion system $(46.4 \%)$ was dictated by receiving information about the offer via direct oral communication. A significant percentage of people also did not refer to the diving events organised (56\%) and logistical organisation by the owner of the visitors' arrivals (42\%), because they never used them. On the other hand, the respondents were able to indicate their expectations in relation to the improvement of the surface $(18.7 \%)$ and underwater infrastructure $(17.3 \%)$ and other facilities that would not only facilitate their stay but also affect the frequency of visits (15.4\%). First and foremost, divers do not have sufficient access to sanitary and catering facilities. The owner solved the shortage of running water, the supply of which would involve very high investment costs by preparing a suitable container for this purpose (Fig. 4), which is part of the overall infrastructure development of the facility (Fig. 5).

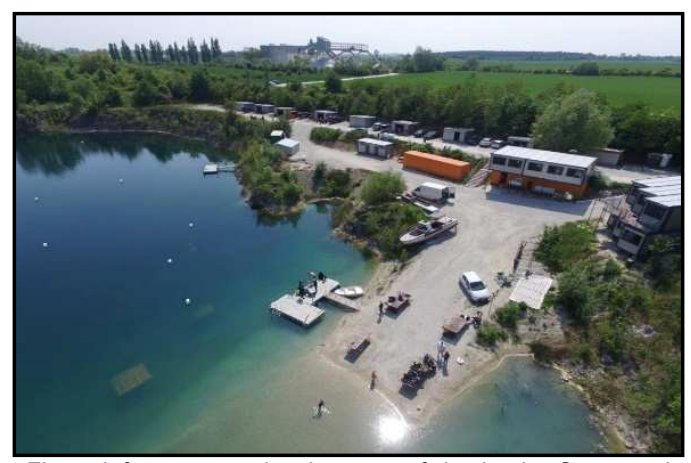

Fig. 5 Infrastructure development of the basin. Source: photograph provided by the owner of CNP (by Robert Werner).

wreck would be circa 200 thousand PLN, which he cannot afford. It was also proposed to flip the sunken wreck of the tugboat and make it available for underwater sightseeing. However, most of the remarks were directed to the changes in the water depth related to the maintenance of proper orientation, namely: introduction of markings on handrails to know in which direction one is going (e.g. LED signposts) and towards what kind of attractions. It was also suggested that the stocking of the basin with fish should be increased. $50.7 \%$ of the respondents were interested in diving with Nitrox breathing mixture and $65.9 \%$ of the respondents were interested in organising events at which diving equipment would be tested. Regardless of the indicated shortcomings of the offer and the expectations placed on the owner of the facility, $54 \%$ of the divers rated the Piechcin site in comparison with other units in the country as very good and $35.2 \%$ as good.

Of the total number of respondents surveyed, $48.6 \%$ confirmed, as in the previous year (48\%), that the development of the facility meets their expectations in every respect. $98.5 \%$ of respondents want to come back here again, but indicate $(90.2 \%)$ that this is not the only place in which they dive. However, for many $(71.2 \%$ vs. $66 \%$ in 2017) it played a very significant role in preparations for diving in larger bodies of water (seas: Adriatic, Baltic, Black, Caribbean, Norwegian, North, Mediterranean, oceans: Atlantic, Indian) and lakes (e.g. Hańcza). The frequency of the respondents' arrivals depends on the lack of time (57 people, i.e. 25.3\%), 
distance between their place of residence and the basin (53 people, i.e. $23.5 \%$ ), price (5 people $-2.2 \%$ ), professional and family related constraints ( 4 people $-1.7 \%$ ), visiting other competitive sites ( 3 people - 1.3\%), lack of an organised social group associating the enthusiasts of the Piechnik reservoir on the Internet (1 person), as well as lack of food on site (1 person).

The results obtained do not differ significantly from those obtained the year before, but should be treated as comparative and complementary. The actual number of people coming to the CNP is higher per year, but the observations made in this respect allow us to assume that the quality of services maintained at a certain level by the owner of the facility translates, to a large extent, into divers' satisfaction with the overall offer.

The enthusiasts of underwater experiences come not only to explore the area for tourism and training purposes, but also to participate in occasional events organised here or national diving and environmental actions, whose intentions are focused on environmental protection (cleaning the bottom of the body of water, the water-bank line and the immediate surroundings of the area). Activities in this area have not only an educational resonance on a regional scale, but also promote the rural area as environmentally friendly. The Piechcin Diving Centre plays an important role in creating conditions for the growth of competitiveness of the economy, based on knowledge and entrepreneurship, ensuring the growth of employment and social, economic and spatial cohesion through its participation in the strategic document National Cohesion Strategy (NCS).

Under the project co-financed by the European Regional Development Fund (ERDF) - Operational Programme of the Kujawsko-Pomorskie Voivodeship it received funding in the amount of PLN 347,490 (including ERDF: PLN 259,370, and the state budget: PLN 52,120), which allowed for the expansion and modernisation of the CNP through the purchase of equipment and services as elements of diversification of the offer, as well as the development of the company. The total value of the investment was PLN 606,870 (PLN 259,380 is the owner's own contribution). According to Bański [18], entrepreneurship in rural areas has a significant impact on the general development of regions, including the improvement of the quality of life in rural areas. The owner, by creating an offer for a specific segment of buyers on the basis of local resources, developed an investment which not only brings tangible financial benefits to him but also to the local community.

\section{Conclusions}

- The research has confirmed the high quality of services provided in the Piechcin base, both in terms of customer service and development of the area. The material background of the services has proved to be the condition which makes the divers want to come here again. Above all, the respondents pointed out the attractiveness of the underwater and shore infrastructure, i.e. those elements which are most important for them for diving purposes.

- The main activities undertaken by the divers at the site are tourist (recreational) or training dives, which the respondents most often undertake in the company of their friends, acquaintances from diving centres or family. They come here in all seasons of the year, with prevalence of summer, to spend time with friends and escape from the duties of everyday life in addition to the passion for diving (improving skills and qualifications).

- The observed deficiencies in the scope of faulty diving equipment (probably caused by errors resulting either from improper use, poor configuration or improper maintenance) did not ultimately affect the overall assessment of the safety level of the basin (a total of $93.4 \%$ of people trusted the organiser and awarded him very good and good marks in this respect). Nevertheless, the perception of the centres clientele of the service (its safety) should ensure that the owner of the facility will in the future properly control the condition of the diving equipment rented in order to reduce the probability of an accident. In the case of diving services, this is one of the most important determinants of the quality of the offer, the reliability of which cannot be compromised.

- When analysing the data on the extent to which the customers' expectations of improving diving conditions have been met, it should be noted that they indicate (as did the respondents last year) that important improvements should be made in the water depths to ensure their comfort and thus safety. The idea is to place appropriate markings that would make it easier for them to penetrate the body of water, to reach all the sunken exhibits, and thus to maintain better orientation in the water.

- Infrastructure shortages noticed by customers did not translate into an overall assessment of the facility and declared intentions regarding returning in the future. It is likely that those who have been visiting the facility for years (a dozen or so times) may feel bored with the same underwater attractions, which is why they mainly suggested improvements in this area.

- The Piechcin site has developed and strengthened its brand over the past years. This is reflected in the customer's trust (recommending the site to other divers, word-of-mouth marketing), the frequency of returns of the same people and the number of new arrivals. This means that the Centre has a good reputation among competitors on the market for these services.

- Surveys conducted among divers may have a cognitive value for other organisations providing (or wishing to provide) similar services, as without knowing the opinions of potential clients, the measures taken may not reflect the expected level of the offer and may be burdened with risk. 


\section{REFERENCES}

1. Skrzyński S. Deep diving in underwater works in Poland, Polish Hyperbaric Research 2(67) 2019, 69-92. http://doi.org/10.2478/phr-2019-0007;

2. Jóźwiak D. Siermontowski P. Dąbrowiecki Z. Olszański R. Analysis of the risk of diving accidents in military and recreational diving, Polish Hyperbaric Research 4(53) 2015, 41-54. DOI 10.1515/phr-2015-0022;

3. Law on entrepreneurs of 6 March 2018. (Journal of Laws 2018 No 646)

4. Law on Associations of 7 April 1989 (Journal of Laws of 7 April 1989). 1989 No. 20 item.104);

5. The Civil Code Act of 23 April 1964 (Journal of Laws 1964 No 16 item 93);

6. The Criminal Code Act of 6 June 1997 (Journal of Laws of 6 June 1997). 1997 no 88 item 553);

7. Standards PN-EN: PN-EN 14467. Recreational diving services. Requirements for service providers; PN-EN 14153-1. Recreational diving services. Minimum safety requirements for the training of recreational divers. Part 1: Level 1 - Supervised diver; PN-EN 14153-2. Recreational diving services. Minimum safety requirements for training of recreational divers. Part 2: Level 2 - Autonomous diver; PN-EN 14153-3. Recreational diving services. Minimum safety requirements for training of recreational divers. Part 3: Level 3 - Diving guide; PN-EN 250. Breathing equipment. Opencircuit compressed-air diving apparatus. Requirements, testing, marking; PN-EN 1809. Diving gear. Buoyancy compensators. Functional and safety requirements, test methods; PN-EN 12628. Diving gear. Rescue and buoyancy equipment. Functionality and safety requirements and test methods; PN-EN 13319. Diving gear. Depth gauges and combined instruments for measuring depth and time. Functionality and safety requirements and test methods; PN-EN 1968. Periodic inspection and testing of steel seamless gas cylinders; PN-EN 1802. Gas cylinders. Periodic inspection and testing of seamless aluminium alloy gas cylinders;

8. https://www.pttk.pl/ks3/dok/k17_u240_z01_20110618.pdf [accessed on 2019-12-7];

9. Zawadzki D. Use of flooded quarries and excavations in specialised tourism - recreational diving. in: Współczesne problemy badań geograficznych, Wybrane problemy geografii turyzmu, Wydawnictwo Naukowe Uniwersytetu Szczecińskiego 2013, str.255-267. https://www.researchgate.net/publication/259930463 [cytowano 2019-12-7];

10. Pietrzyk-Sokulska E. Water reservoirs in post-mining excavations - a new element of attractiveness of the city landscape. In: KRAJOBRAZ A TURYSTYKA, Prace Komisji Krajobrazu Kulturowego No. 14, Komisja Krajobrazu Kulturowego PTG 2010, 264-272. ISSN: 1896-1460, ISBN: 978-83-61695-06-6;

11. Pietrzyk-Sokulska E. Quarry water reservoirs as a new landscape element. Przegląd Geologiczny, vol.63, no. 8 2015: 464-469, bwmeta1.element.baztech-c645369b-8b5c-48f3-acd1-a6b38f467598 [accessed on 2019-12-7];

12. Berbeka J. Interdependence of diving and tourism. In: Gaworecki W.W, Mroczyńska Z. redaktorzy. Turystyka i sport dla wszystkich w promocji zdrowego stylu życia. publ. Gdańsk WSTiH; 2008, 457-458. ISBN: 978-83-7531-072-6;

13. bazapiechcin.eu/index.php?option=com_content\&view=article\&id=52\&ltemid=59 [accessed on 2019-12-7];

14. albikrosno.pl/wykaz-stopni-nurkowych [accessed on 2019-12-7];

15. nurkowanienapoleon.pl/stopnie-nurkowe/ptn-pletwonurek-turystyczny-nadzorowany/ [accessed on 2019-12-7];

16. https://www.underwater.pl/kursy-nurkowania/padi-divemaster.html [accessed on 2019-12-7];

17. Cichowska J., Garbacz J.K, Ciechalski J. The role of the Piechcin base in the development of specialised tourism with a view to diver preparation for penetration of the Baltic Sea. Polish Hyperbaric Research 2018 2(63), 51-61. DOI: 10.2478/phr-2018-0013;

18. Bański J. Conditions for the development of entrepreneurship in rural areas - selected issues. In: Roczniki Naukowe Ekonomii Rolnictwa i Rozwoju Obszarów Wiejskich. T. 102, Z.1 2015, 59-69. ISSN 2353-4362.

dr Jolanta B. Cichowska

Uniwersytet Technologiczno-Przyrodniczy im. Jana i Jędrzeja Śniadeckich w Bydgoszczy Wydział Budownictwa, Architektury i Inżynierii Środowiska

Zakład Inżynierii Środowiska

ul. Sucha 9, 85-789 Bydgoszcz

Tel. (52) $3408261 / 3408440$ 